\title{
Chest pain as a rare presentation of multiple myeloma
}

\author{
M R Siddiqui, Q T Islam, A Hossain, Y U Rahman, M S Mahbub, M J lqbal, F Naz
}

Department of Internal Medicine, Dhaka Medical College Hospital, Dhaka, Bangladesh

Correspondence to M R Siddiqui, dr.mahmud99@yahoo.com

\section{DESCRIPTION}

A 65-year-old man presented with left lower chest pain for 2 months and low grade intermittent fever for 1 month. Pain was dull aching, more marked during movement and partially subsided after taking non-steroidal anti-inflammatory drugs. Examination revealed anaemia and tenderness in left fourth, fifth ribs, intercostal space in the mid axillary line. All other clinical examinations were normal. Investigations revealed complete blood count: $\mathrm{Hb}-7.1 \mathrm{~g} /$ $\mathrm{dl}$, erythrocyte sedimentation rate (ESR) $-140 \mathrm{~mm}$ in first hour, peripheral blood film - normocytic normochromic anaemia with marked rouleaux formation. Chest x-ray revealed a mass of the left chest wall with rib destruction suggestive of malignant pleural mesothelioma. A CT scan (figures 1-3) showed a spindle shaped $4 \times 6 \mathrm{~cm}$ tumour, localised at the lateral angle of the fourth, fifth rib and growing intrathoracic, with destruction of the fourth rib. The mass was relatively well demarcated and there were no cystic components. There was no evidence of lung or lymph node metastasis. CT-guided fine-needle aspiration of the chest wall mass showed an increasing number of plasma cells. With these clinical contests our next investigation of choice was bone marrow examination, which revealed marrow was infiltrated with around $90 \%$ of both typical and atypical plasma cells including plasmablast. We therefore diagnosed this tumour as multiple myeloma $(\mathrm{MM})$. Chest pain is a very unusual presentation of multiple myeloma. Isolated chest wall mass without any other skeletal involvement is even rarer. MM often produces gross sternal expansion, distortion and vertebral body

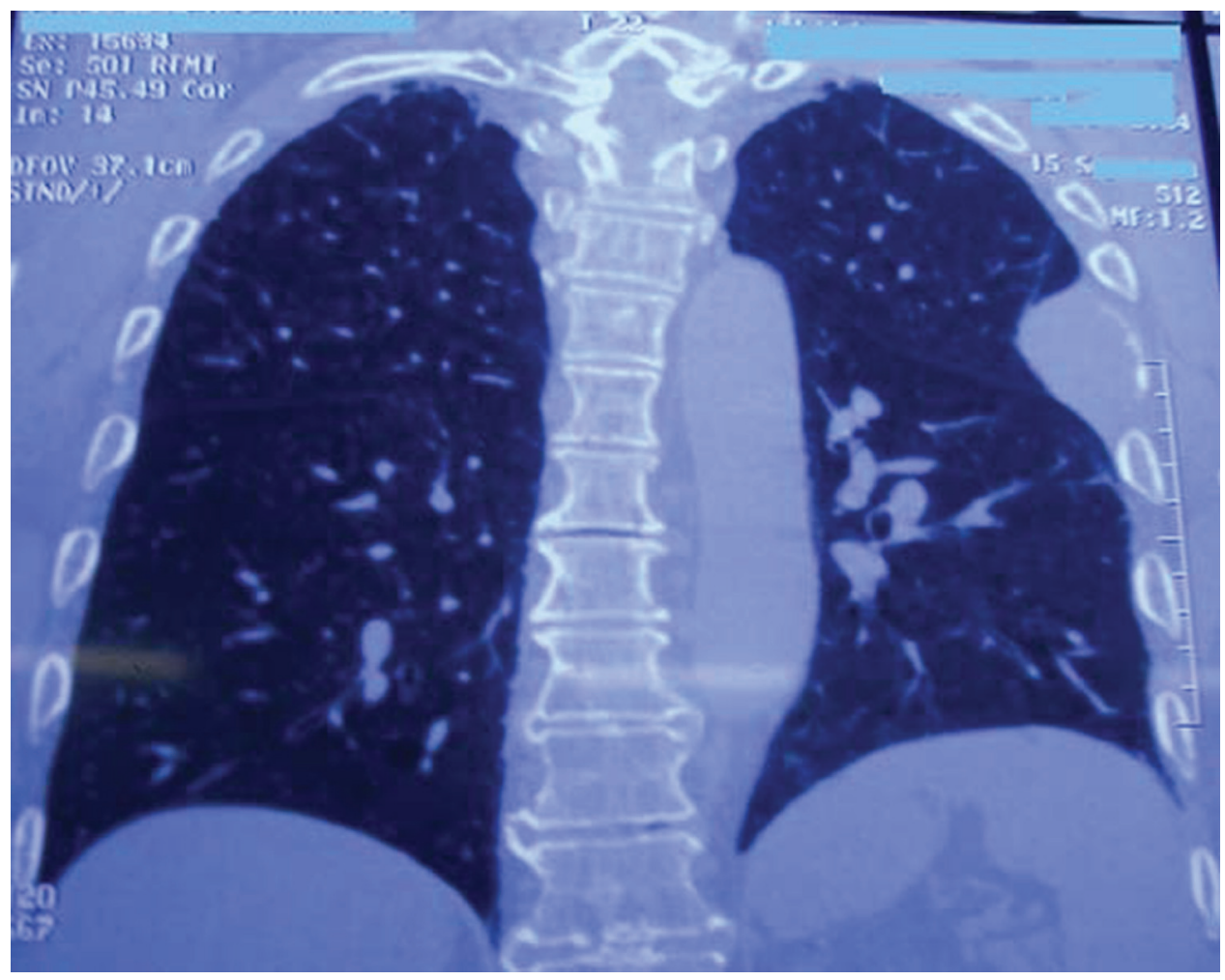

Figure 1 Coronal CT scan of chest shows a mass of the left chest wall with fourth rib destruction. 


\section{BMJ Case Reports}

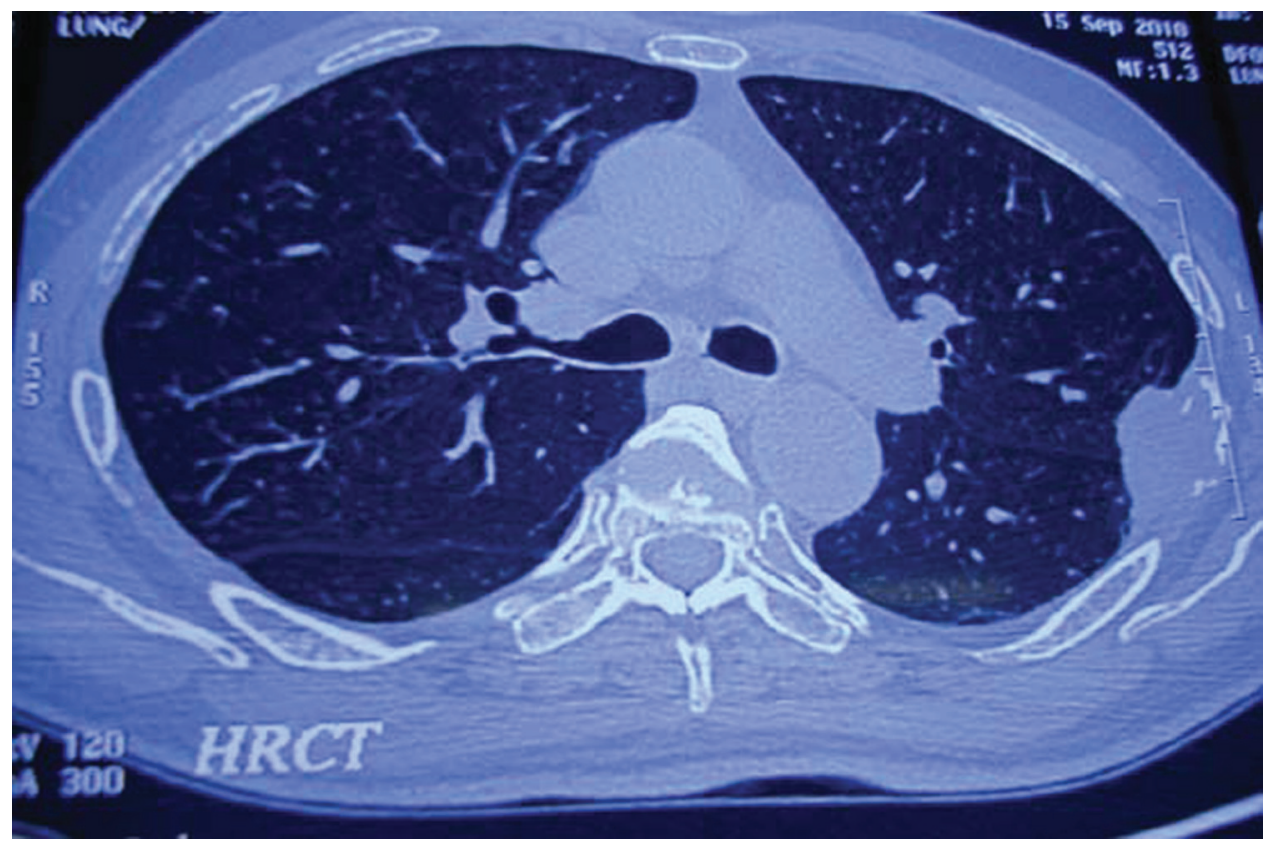

Figure 2 High resolution axial lung window CT scan of chest shows a spindle shaped $4 \times 6 \mathrm{~cm}$ tumour, localised at the lateral angle of the fourth, fifth rib and growing intrathoracic, with destruction of the fourth rib.

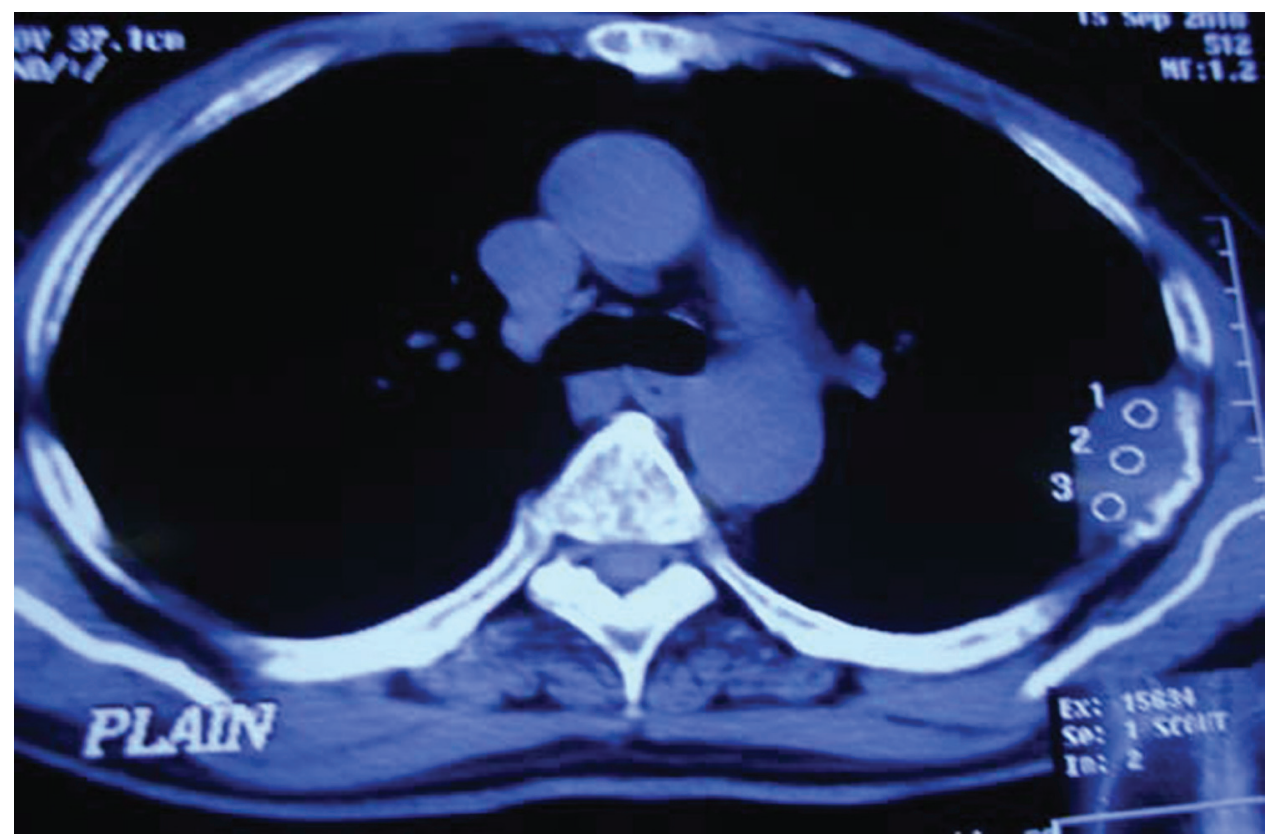

Figure 3 Axial mediastinal window CT scan of chest shows a spindle shaped $4 \times 6 \mathrm{~cm}$ tumour, localised at the lateral angle of the fourth, fifth rib and growing intrathoracic, with destruction of the fourth rib.

destruction. ${ }^{1}$ The growth of these cells in the bone marrow can cause expansion and remodelling of bones even within the chest wall. ${ }^{1}$ But chest wall involvement with mass lesion is very uncommon. ${ }^{2}$

Competing interests None.

Patient consent Obtained.

\section{REFERENCES}

. O'Sullivan P, O'Dwyer H, Flint J, et al. Malignant chest wall neoplasms of bone and cartilage: a pictorial review of CT and MR findings. Br J Radio 2007:80:678-84.

2. Oymak FS, Karaman A, Soyuer l, et al. Pulmonary and chest wall involvement in multiple myeloma. Tuberk Toraks 2003;51:27-32. 


\section{BMJ Case Reports}

This pdf has been created automatically from the final edited text and images.

Copyright 2011 BMJ Publishing Group. All rights reserved. For permission to reuse any of this content visit http://group.bmj.com/group/rights-licensing/permissions.

BMJ Case Report Fellows may re-use this article for personal use and teaching without any further permission.

Please cite this article as follows (you will need to access the article online to obtain the date of publication).

Siddiqui MR, Islam QT, Hossain A, Rahman YU, Mahbub MS, Iqbal MJ, Naz F. Chest pain as a rare presentation of multiple myeloma. BMJ Case Reports 2011;

10.1136/bcr.01.2011.3765, date of publication

Become a Fellow of BMJ Case Reports today and you can:

- Submit as many cases as you like

- Enjoy fast sympathetic peer review and rapid publication of accepted articles

- Access all the published articles

Re-use any of the published material for personal use and teaching without further permission

For information on Institutional Fellowships contact consortiasales@bmjgroup.com

Visit casereports.bmj.com for more articles like this and to become a Fellow 